\title{
THE PARAMETRISATION OF LEGAL TERMINOLOGY CONCERNING CHILD MAINTENANCE SUPPORT IN THE SWEDISH AND POLISH LEGAL SYSTEMS
}

\begin{abstract}
This paper deals with translating legal terminology concerning child maintenance from Polish to Swedish. The analysis covers selected terms regulated in the Polish civil law and their possible Swedish equivalents. The method used is based on the parameterisation of legal terms, which allows the specification of terms by selected parameters, which are understood as mutually exclusive properties. The parameterised equivalents are analysed in the context of various types of recipients. This provides the basis for the choice of appropriate translation strategies. The author also discusses pragmatic equivalents featured in Rikstermbanken, the Swedish national terminological database, and those used in practice.
\end{abstract}

Keywords: legal translation, legal terms, Polish-Swedish translation, parameterisation, maintenance.

\section{Introduction}

As a result of the sizable migration of Poles to Sweden, the number of family law cases between these two countries is growing, in particular related to maintenance. Essential for families is maintenance, which is regulated by somewhat different procedures under Polish and Swedish legal systems. Moreover, migrants are also subjected to regulations based on international and EU law. Therefore translating documents pertaining to maintenance may pose problems. The objective of the present study is to show that the parameterisation of legal terminology makes it easier to find terminological equivalents.

\section{Methods}

When looking for equivalents for Polish terms, I mainly resort to the method based on the parameterisation of legal terms (Matulewska 2013) in Polish-Swedish language pair ${ }^{1}$. I shall explain this method in more detail 


\section{Milena Hadryan}

in section 4 below. I shall also make use of comparison of parallel texts (Delisle 1999), in this instance Polish and Swedish legislation. The skopos theory (cf. Vermeer 2001) will be used when translating terms, together with the model of pragmatic translation of legal texts, with the particular emphasis on the recipient's imperative (Kierzkowska 2002).

The skopos theory lends particular importance to the pragmatic aspects of the translated text: the form of the target text must primarily focus on the function of the text in the target language. According to Kierzkowska (2002: 199), 'the recipient's imperative' is a concept that implies objectively existing needs and purposes to be satisfied by the translation recipient. The following types of recipients are distinguished: close recipient, distant recipient and self-defined recipient. It is assumed (Kierzkowska 2002: 8889) that, in contrast to a distant recipient (e.g. a tourist or general interest reader), a close recipient is familiar with the culture of the source language or is motivated to become familiar with it (e.g. lawyers, students, translators); finally, a self-defined recipient relies on and as a customer insists on his/her own preferred terminology (e.g. a publishing house or a company).

The determination of the recipient's type is the first step in Kierzkowska's pragmatic translation model of legal texts. The second step is to establish terminological usage, this would motivate translators to take into account the already existing prescriptive terminology, national and international. Finally, the appropriate translation strategy (type of equivalence) can be chosen. According to Koller (1995), denotative equivalence is suitable for a close recipient, for a distant recipient - connotative equivalence and for a self-defined recipient - pragmatic equivalence. I shall apply the latter model of establishing equivalence in my study.

\section{The parallel text corpus. Other sources of legal definitions and equivalents}

The research of parallel texts covers the following Polish and Swedish legislation:

- the Polish Family and Guardianship Code (Kodeks rodzinny i opiekuńczy, KRO),

- Act on the Assistance to Persons Entitled to Maintenance (Ustawa o pomocy osobom uprawnionym do alimentów, Uspoudo),

- the Swedish Parental Code, chapter 7 on maintenance obligation (Föräldrabalk, 7 kap Om underhållsskyldighet) and

- Social Insurance Code (Socialförsäkringsbalken). 
I have also availed myself of definitions from Rikstermbanken ${ }^{2}$, the Swedish national term base, and equivalents from the selected dictionaries.

\section{Parameterisation of legal terms}

Before I begin the presentation, I am going to explain my understanding of parameterisation. Every legal term has a number of features which are essential when seeking an equivalent. For example, maintenance is a legal term. Thus its distinguishing property is being part of legal language, as opposed to, for example, the vernacular language. A parameter, on the other hand, means a collection of properties of the same type, which are mutually exclusive (e.g. legal language, vernacular, LSP). Here, the parameter (which is also called 'dimension'), is the lect. The terms designating maintenance in Swedish and Polish represent the legal lect.

In order to carry out a systematic comparison of terms in any language pair, the same relevant parameters need to be taken into consideration. Those parameters allow the determination of precise characteristics of a term. Where two terms share the same property under a specific parameter, they are convergent for that parameter (e.g. the term alimenty for the parameter 'lect', which is 'legal language' in both cases). If, however, the terms represent various properties, they are complementary. For example, complementarity relates to the legal reality of the source text (Common Law, Civil Law, etc.).

As regards the Swedish legal system there are reasons to classify it neither as common law nor as the civil law, but rather belonging to the Nordic legal family:

Although traditionally thought of as a civil law system, the Swedish legal system fits neither fully the category of a civil law or common law country. It is not entirely the former as it does not have a complete codification such as Bürgerliches Gesetzbuch ('BGB') or the Napoleonic Code. (...) In contrast, certain areas of law, such as perfecting security interests in chattel papers (sakrätt), are almost entirely regulated by case law with little or no statutory provisions. However, Sweden equally does not fit perfectly within the common law designation, particularly in light of the perception of the role of the judiciary. (Carlson 2012, 38-39)

The aim of parameterisation in this research was to establish whether the term is sufficiently equivalent to be used in translation for a specific 
recipient. I consider the following parameters (= dimensions) required for the purpose of this research:

- branch of law

- sub-branch of law

- text genre

- text sub-genre

- lect

- the reality of the source text

- general meaning of the term

- a distinguishing feature in the meaning of the terms in L1 and L2.

In the following, two Polish legal terms and their possible equivalents will be analysed according to the above parameters.

\section{Term 1: Alimenty (maintenance)}

In line with the purposes of this analysis, the meaning of alimenty is restricted here to alimenty na dzieci (maintenance payments for children); in both the Polish and Swedish legal systems maintenance can benefit a wide group of recipients, e.g. spouses or former spouses). To establish the equivalent in the target language (L2) for a term in the source language (L1), initially a list of relevant parameters is drawn up that describe the term in L1. Then, a potential L2 equivalent is selected by comparing parallel texts.

That potential equivalent can also be selected with the help of dictionaries. The next step involves describing terms in L1 and L2 on the basis of parallel texts. For the term alimenty one of the general-purpose dictionaries (Kubitsky 1995), offers two equivalents:

\section{L1: alimenty L2: underhållsbidrag, underhåll till barn} (maintenance, child support)

Both Swedish equivalents are synonyms found in the legislative text (Föräldrabalk, 7 kap.). I will, however, restrict myself here to the term underhållsbidrag, because the term underhåll also constitutes a hyperonym for the term underhållsbidrag and the term underhållsstöd (which I will analyse in table 2). This choice is consistent with the contents of the national terminology database Rikstermbanken, available on the Internet. This source merely provides the definition of the term underhållsbidrag. It is noteworthy that the Polish-Swedish dictionary entry is not precise, failing to indicate the restriction in the meaning of the Polish term. Subsequently, on the basis of the definition of the term in parallel texts, properties are highlighted 
which define the meaning of both terms. It is sometimes advisable to clarify definitions found in legislative texts with the help of commentaries on legislation, case law or, as Swedish resources make this possible, use of national terminology databases.

The legislative text defines the term alimenty in L1 as follows:

\section{Article 133 KRO}

$\S 1$. Parents shall provide maintenance to a child that is still unable to provide for him/herself, unless income from the child's assets sufficiently cover the costs of living and raising the child.

$\S 2$. Apart from the above, only those living in poverty shall be entitled to maintenance payments.

$\S 3$. Parents may withhold maintenance payments to a child of full age, if these cause them excessive hardship or if the child undertakes no efforts to gain self-sufficiency.

According to the commentary to the act (Ignaczewski 2014: 81), it does not specify the age limitation of a child entitled to parents' maintenance subject to the above reservations. It is commented in passing that this regulation represents a certain progress towards liberating parents from the obligation to provide to adult children: the previous version of the act forced parents to share 'the last piece of bread' with even mature children.

Article 96 of the KRO places an obligation on the parents to care for the physical and spiritual development of their child as well as to prepare him/her properly to work for the good of society according to his/her abilities. The commentary to this regulation suggests that the proper preparation for the working life may also include university studies, where the talent, ambition and determination are sufficient. Parents will not have to provide for their adult children who neglect studies, fail examination and do not complete their courses within the normal duration of the course (Ignaczewski 2014: 84-85). In Article 135 Section 1 the Act stipulates that the extent of the maintenance payment depends on the reasonable needs of the child, earning potential and financial position of the parent (Ignaczewski 2014: 24).

To summarise the Polish regulations, due to the fact that the compulsory school age is 18 , a child is usually entitled to maintenance payments until he/she reaches maturity, or even until he/she completes tertiary education. Children over 18 years are no longer entitled to receive maintenance. That right is not forfeited for those children, who continue education (e.g. enrol for university courses) or whose health condition or personal circumstances require the continuation of payments. However, parents will not 
have to provide for their adult child who falls back in studies and, as a result, fails to complete the course on time.

The Swedish term underhållsbidrag has been defined twofold in the national terminology database Rikstermbanken:

1) bidrag som en förälder som inte bor med sitt barn ska betala till barnets försörjning

maintenance to be paid by the parent who does not live with his/her child

2) belopp som en förälder som inte bor tillsammans med sitt barn ska bidra med till barnets försörjning

amount to be paid towards the maintenance of his/her child by the parent who does not live with the child

Equivalents are also offered in several languages, including English (child support), German (Kontaktzuschuss), French (pension alimentaire), Spanish (pensión alimenticia) and Polish (alimenty).

Swedish legislation's definition of the term underhallsbidrag is less ambiguous than its Polish equivalent. Under the Swedish Parental Code [Föräldrabalken] parents are responsible for their children's provision until they come of age or until they become capable of providing for themselves. If the child attends school, parents have to provide for them as long as they are of cumpulsory school age (primary or secondary school), i.e. until the child completes 21 years (7:1 FB).

A comparison of Polish and Swedish term definitions shows that the age limit before which the child may claim maintenance, is regulated differently in the legal systems of both countries. This issue may therefore emerge as one of dimensions relevant for the term alimenty. Table 1 enlists the relevant parameters selected for the Polish and Swedish terms.

Table 1

Parametric characteristics of the terms alimenty and underhållsbidrag (maintenance)

\begin{tabular}{|c|c|c|}
\hline \multirow{2}{*}{ Parameter } & \multicolumn{2}{|c|}{ Terms } \\
\hline & L1: alimenty & L2: underhållsbidrag \\
\hline Branch of law & Civil law & Civil law \\
\hline Sub-branch of law & Family law & Family law \\
\hline Text genre & Legislation & Legislation \\
\hline Text sub-genre & Code (Polish Civil Code) & Code (Swedish Code) \\
\hline Lect & Legal language ${ }^{3}$ & Legal language \\
\hline Sub-lect & Language of law & Language of law \\
\hline
\end{tabular}


The Parametrisation of Legal Terminology Concerning Child Maintenance...

\begin{tabular}{|l|l|l|}
\hline \multirow{2}{*}{ Parameter } & \multicolumn{2}{|c|}{ Terms } \\
\cline { 2 - 3 } $\begin{array}{l}\text { The reality of the source } \\
\text { text }\end{array}$ & Civil law & \multicolumn{1}{|c|}{ L2: underhällsbidrag } \\
\hline $\begin{array}{l}\text { General meaning of the } \\
\text { term }\end{array}$ & $\begin{array}{l}\text { Financial support by par- } \\
\text { ents towards the cost of liv- } \\
\text { ing and education of their } \\
\text { children. Support level de- } \\
\text { pends on the needs of the } \\
\text { child and financial situa- } \\
\text { tion of the parents. [KRO, } \\
\text { Articles 96, 128, 133, 135] }\end{array}$ & $\begin{array}{l}\text { Financial and other rea- } \\
\text { sonable support by parents } \\
\text { ing with them. [FB, section } \\
7(1), \text { (2)] Support level de- } \\
\text { pends on the needs of the } \\
\text { child and financial situation } \\
\text { of he parents. [FB, section } \\
7(1)]\end{array}$ \\
\hline Claim period & $\begin{array}{l}\text { Up to the age of 18 or max. } \\
\text { until completion of tertiary } \\
\text { education. [KRO, Article } \\
\text { 133] }\end{array}$ & $\begin{array}{l}\text { Up to the age of 18, i.e. on } \\
\text { completion of compulsory } \\
\text { education, max. until the } \\
\text { age of 21. [FB, section 7(1)] }\end{array}$ \\
\hline
\end{tabular}

A comparison of the terms alimenty (L1) and underhaillsbidrag (L2) performed on the basis of the specified parameters leads to the conclusion that these terms are fairly coincident. According to Kierzkowska (2002: 119), they are to be considered natural close equivalents. The Swedish legislation defines maintenance explicitly as a payment provided by the parent who does not live with the child; an essentially similar stipulation, but from a different perspective - contains the Polish act: the provision of maintenance (entirely or in part) may be effected in the form of personal endeavours to raise a child (Article 135(2), which in practice would involve the parent living with the child.

There are certainly also other legal differences between Polish and Swedish maintenance. For example, in Sweden overdue payments are subject to enforcement for a period of a maximum 5 years, while in Poland up to 3 years. However, these details are better left to lawyers. Still, the length of claim period, specified in core legislation, should be a matter of interest for the translator, even more so where this issue is to be considered by the court. Let us look at three situations:

\section{Case 1}

Piotr K., living in Poland, receives support as ordered by the court from his father resident in Sweden. Piotr will soon be 18, take his final school examination and hopes to go to university. To continue receiving support he will have to request an extension before his $18^{\text {th }}$ birthday (Ignaczewski: 529). 


\section{Milena Hadryan}

The relevant application must be filed, together with the translation, with the appropriate Court of Appeal (Svea Hovrätt). Should Piotr K. (or the appropriate court in Poland) fail to indicate in his application that under Polish law he has the right to maintenance as long as he is in education, then the sworn translator involved with the translation of the documents must do it. Although the general guidelines for translators (Kierzkowska 2011) instruct us to treat the Swedish court as a remote recipient, i.e. one who is not interested in exploring the intricacies of the Polish legal system, yet I believe that in this specific case, where the source term comprises the issue of this application, this principle may be overruled. In my opinion we are facing an exception, as the court in Sweden is very much interested in the basic differences in the meaning of the two terms. Therefore I would expect the translator to highlight this difference, for example in the form of a following footnote:

Translator's note: Maintenance in Poland can be claimed up to the completion of tertiary education, see Article 133 of the Family and Guardianship Code.

Of course, the main responsibility for the substantiation of the application rests on the applicant.

\section{Case 2}

The Polish court has awarded the mother of a 2-year-old Sebastian R. maintenance from the child's father, whose domicile is in Sweden. The court files the application for recognition and a declaration of enforceability of the foreign judgment, together with the translation, with the appropriate Court of Appeal (Svea Hovrätt). When translating the judgment, the translator does not need to explain the term alimenty. The Swedish court is again the recipient, but in this case the issue of how long the payment can be made is not relevant. If, for example, Sebastian R. completes his education by the time he is 18 , he will no longer be entitled to payments after that date.

To sum up, the results of the parametric analysis suggest that the Polish term alimenty and the Swedish term underhållsbidrag are approximate equivalents. As, however, both systems differently define the maximum age, the foreign term may on occasions require additional clarification by the translator. Such need arises when, for example, the recipient is close, and the issue of the length of claim period is central in the case. 
Term 2: świadczenie $z$ funduszu alimentacyjnego (payments from the maintenance fund)

Another Polish term analysed here is świadczenie z funduszu alimentacyjnego. This is a benefit paid from the public funds to children who do not receive maintenance. It is regulated by the Act of 2007 on the support to persons entitled to maintenance (Uopouda). Already in the preamble it sets out the circle of beneficiaries. They are individuals who are in a difficult financial situation as they are unable to enforce maintenance. There is no age difference compared to maintenance recipients: up to 18 years, or 25 if the recipient continues education (Article 9.1.) Disabled persons qualify with no time limit. The act stipulates an income threshold (Article 9.2): the family income per person may not exceed $725 \mathrm{PLN}^{4}$. The amount paid out corresponds to the maintenance previously awarded by the court, however it is no more than 500 PLN per child monthly. The act also places government bodies under an obligation to seek enforcement of due maintenance from the debtor. This includes not only an effective enforcement by a bailiff, but also other administrative measures against the debtor; for example, the act gives the powers to force the debtor to register as unemployed or remove from him/her a driving licence.

No Swedish equivalent for the term świadczenie z funduszu alimentacyjnego can be found in the Polish-Swedish dictionary. We will find one, underhållsstöd, when analysing the parallel text to the Polish legislation, (The Parental Code, section 7, 2a §). Underhållsstöd is also a connotative equivalent, whether the denotative equivalent may be förmåner från underhaillsfonden (payments from the maintenance fund), which could be established with the help of the existing databased dictionary Glosbe ${ }^{5}$ on the Internet.

This benefit is awarded in Sweden to persons who are not in receipt of maintenance they are entitled to, because the obligor fails to pay or is no longer alive. The legal basis constitutes the Social Insurance Code (Socialförsäkringsbalken). The amount paid is fixed (1,573 SEK monthly per child), however there is no family income threshold here. A child qualifies if he/she lives with at least one parent or alternately with one or the other, while having his/her official domicile at one parent's only (Socialförsäkringsbalken, SFB 2010:110). Underhållsstöd is paid to the parent with whom the child lives.

The Swedish term underhållsstöd (L2) has been defined in the national terminological database Rikstermbanken twofold:

1) ersättning när en förälder som bor med sitt barn inte fär avtalat eller 
tillräckligt underhållsbidrag från den andra föräldern

the benefit is payable if the parent living with the child, receives from the other parent no maintenance in the agreed or sufficient amount

2) stöd som den ene föräldern kan få om den andre föräldern inte bor tillsammans med sitt barn och inte betalar underhållsbidrag eller betalar ett lägre belopp än 1573 kronor per månad

the maintenance which either parent can receive if the other does not live with the child or pays less than 1,573 SEK monthly

Equivalents in several languages were also provided, including in English (maintenance support), German (Unterhaltsbeihilfe), French (aide alimentaire), Spanish (ayuda alimenticia) as well as three in Polish (zaliczka alimentacyjna; zasitek na utrzymanie; zasitek alimentacyjny).

A comparison of the Swedish and Polish definitions reveals that the family income as a qualifying threshold sets apart both terms. This aspect may be deemed one of dimensions relevant for the term swiadczenie z funduszu alimentacyjnego. Table 2 presents the relevant parameters selected for the Polish and Swedish term.

Table 2

Parametric characteristics of the terms świadczenie z funduszu alimentacyjnego and underhållsstöd

\begin{tabular}{|c|c|c|}
\hline \multirow[b]{2}{*}{ Parameter } & \multicolumn{2}{|c|}{ Terms } \\
\hline & $\begin{array}{c}\text { L1: świadczenie z funduszu } \\
\text { alimentacyjnego }\end{array}$ & L2: underhållsstöd \\
\hline Branch of law & Civil law & Civil law \\
\hline Sub-branch of law & Administrative law & Social insurance law \\
\hline Text genre & Legislation & Legislation \\
\hline Text sub-genre & Act (Polish act) & Code (Swedish Code) \\
\hline Lect & Legal language & Legal language \\
\hline Sub-lect & Language of law & Language of law \\
\hline $\begin{array}{l}\text { The reality of the source } \\
\text { text }\end{array}$ & Civil law & Nordic legal family \\
\hline $\begin{array}{l}\text { General meaning of the } \\
\text { term }\end{array}$ & $\begin{array}{l}\text { A benefit paid from the } \\
\text { state budget to children } \\
\text { who do not receive main- } \\
\text { tenance (Uopouda, Article } \\
9.1 \text { ). }\end{array}$ & $\begin{array}{l}\text { The upper limit is set } \\
\text { (Uopouda, Article 10.1). } \\
\text { The benefit is payable if the } \\
\text { parent living with the child, } \\
\text { receives from the other par- } \\
\text { ent no maintenance in the } \\
\text { agreed or sufficient amount } \\
\text { (SFB 2010:110). The up- } \\
\text { per limit is set (SFB, IV, } \\
\text { section } 17(20) \text {. }\end{array}$ \\
\hline
\end{tabular}


The Parametrisation of Legal Terminology Concerning Child Maintenance...

\begin{tabular}{|l|l|l|}
\hline \multirow{2}{*}{ Parameter } & \multicolumn{2}{|c|}{ Terms } \\
\cline { 2 - 3 } & \multicolumn{1}{|c|}{$\begin{array}{l}\text { L1: świadczenie z funduszu } \\
\text { alimentacyjnego }\end{array}$} & \multicolumn{1}{|c|}{ L2: underhållsstöd } \\
\hline $\begin{array}{l}\text { A qualifying income } \\
\text { threshold }\end{array}$ & $\begin{array}{l}\text { Yes (Uopouda, Article } \\
91.2) .\end{array}$ & No. \\
\hline
\end{tabular}

Let us now consider three scenarios from the translatory practice, where the parameter at the bottom of the table may be essential for the selection of the translating strategy. In case 3 a court of law is the recipient.

\section{Case 3}

Katarzyna C., living in Poland, receives no maintenance from her father, a Swedish national. The support was awarded by a Polish court. Pursuant to Directive of the Council No 4/2009, Katarzyna C. may seek redress before the receiving authority in Sweden, Försäkringskassan, through the appropriate Polish regional court (sąd okręgowy). The mother of Katarzyna C. seeks on her behalf enforcement of maintenance payment for the previous five years. She explains that her daughter entirely relies on the mother to provide for her, as she has no recourse to payments from the maintenance fund. And again: although the Swedish court is, essentially, a distant recipient (Kierzkowska 2011: 15), who is merely interested in summarised information, anyone translating the documents should exercise caution: while the application filed by the mother of Katarzyna C. contains no reference to the income threshold as the qualifying factor for the access to the maintenance fund payments, the translator can fill this gap. He/she should make use of the Swedish connotative equivalent underhållsstöd, adding, e.g. in a footnote, the following translator's note:

Translator's note: The benefit is payable if the family monthly income per head does not exceed 725 PLN (Act of 2007 on the support to persons entitled to maintenance, Article 9.1).

Since the above recipient would be expected to show interest in the difference between the terms in L1 and L2, I suggest introducing a new category and call him a 'quasi remote recipient'.

The recipient in the following scenario is a reader of a translated novel. 


\section{Case 4}

The protagonist of a Polish novel is a young man aged 16, waiting for his pocket money which his mother gives him on receipt of payments from the maintenance fund. The translator working on the Swedish version will no doubt choose the connotative equivalent (underhållsstöd). He/she will not further explain it, as a Swedish reader of this book is a distant recipient, not interested in the details of this benefit.

Discussing the above scenarios we have focused on distant recipients including those who may need to be aware of any specific difference in the meaning between terms in L1 and L2. The following case features a close recipient, among whom Kierzkowska (2011: 15) mentions "foreign companies, whose employees, foreign speakers, are familiar with the realities of life in Poland or are motivated to get to know them".

\section{Case 5}

Göran S., employee of the Gdańsk-based branch of a Swedish company, became the father of the child born to Grażyna K., who lives in Gdańsk. Göran has acknowledged his paternity, but has neither intention to get married nor involved in a long-term relationship. Therefore Grażyna K. would like to agree maintenance with him. The interpreter assisting the mother with informal negotiations will probably resort to natural and connotative equivalents:

- alimenty > underhåll (hyperonym) or underhållsstöd

- świadczenie z funduszu alimentacyjnego (coll. alimenty z funduszu) $>$ polskt underhållsstöd

The following table sums up the Polish-Swedish terminology established above.

Table 3

Swedish equivalents (L2) for Polish terms (L1) alimenty and świadczenie z funduszu alimentacyjnego

\begin{tabular}{|l|l|l|l|}
\hline L1 & \multicolumn{2}{|c|}{ L2 } \\
\hline & Close recipient & Distant recipient & $\begin{array}{l}\text { Distant recipient } \\
\text { who needs to be } \\
\text { aware of the differ- } \\
\text { ences between L1 } \\
\text { and L2 (= quasi } \\
\text { distant recipient) }\end{array}$ \\
\hline
\end{tabular}


The Parametrisation of Legal Terminology Concerning Child Maintenance...

\begin{tabular}{|l|l|l|l|}
\hline \multicolumn{1}{|c|}{ L1 } & \multicolumn{3}{|c|}{ L2 } \\
\hline Alimenty & $\begin{array}{l}\text { Underhåll, } \\
\text { underhållsbidrag }\end{array}$ & Underhållsbidrag & $\begin{array}{l}\text { Underhållsbidrag }+ \\
\text { translator's note }\end{array}$ \\
\hline $\begin{array}{l}\text { Świadczenie z fun- } \\
\text { duszu alimenta- } \\
\text { cyjnego (coll. ali- } \\
\text { menty z funduszu) }\end{array}$ & $\begin{array}{l}\text { Polskt } \\
\text { underhållsstöd }\end{array}$ & Underhållsstöd & $\begin{array}{l}\text { Underhållsstöd }+ \\
\text { translator's note }\end{array}$ \\
\hline
\end{tabular}

\section{A self-defined recipient and customer in Swedish-Polish translation}

We have not yet spoken of self-defined recipients and customers. A good example of such is the Swedish Social Insurance Agency (Försäkringskassan). Its task is to seek recovery of maintenance payments across international frontiers. It corresponds with debtors, also in Poland. As a result, the relevant Swedish-Polish terminology exists already ${ }^{6}$, used by translators working for the Agency. In the model of pragmatic translation of legal terms, Kierzkowska (2002: 85) considers establishing a terminological usage the second stage of translation process, after establishing the type of the recipient. Table 4 presents a list of equivalents collected from Polish and bilingual information materials published by Försäkringskassan.

Table 4

Established Polish equivalents (L2) for the Swedish terms (L1) underhâllsbidrag and underhällsstöd in the translations commissioned by Försäkringskassan

\begin{tabular}{|l|l|}
\hline \multicolumn{1}{|c|}{ L1 (Swedish) } & \multicolumn{1}{c|}{ L2 (Polish) } \\
\hline & Self-defined recipients and customer \\
\hline Underhållsbidrag & Alimenty \\
\hline Underhållsstöd & $\begin{array}{l}\text { 1. zaliczka alimentacyjna (preferred term) } \\
\text { 2. zasitek na utrzymanie } \\
\end{array}$ \\
& 3. zasitek alimentacyjny \\
\hline
\end{tabular}

The sole equivalent used for the term underhaillsbidrag (L1) is alimenty (L2). As demonstrated above, the differences between terms L1 and L2 are only insignificant. Moving to underhållsstöd (L1), the national terminological database Rikstermbanken offers three equivalents. Material available on the Försäkringskassan website indicates a preference for equivalent 1 , zaliczka alimentacyjna (L2). None of the existing equivalents does not attempt to establish a link to the Polish świadczenie z funduszu alimen- 


\section{Milena Hadryan}

tacyjnego. This is entirely justified, given the different origin of both benefits. Choosing a denotative equivalent, similar to the Polish term (e.g. swiadczenie ze szwedzkiego funduszu alimentacyjnego = payments from the Swedish maintenance fund) could lead to confusing these benefits. Moreover, the designation of the Polish benefit is long and functions only in the language of the law and legal practice, but it is not used at the colloquial level. Hence the pragmatic equivalence (zaliczka alimentacyjna) is the correct solution. Given a widespread operation by Försäkringskassan and the resulting impact of its texts, using these equivalents in Swedish-Polish translations is advisable.

\section{Summary and conclusions}

The analysis involved two basic Polish and Swedish terms relating to the area of maintenance. Both were described in the context of their legal systems by means of parameterisation. The parametric approach proved useful. Although the difference in the meaning of these terms turned out to be insignificant, at the subsequent stage of analysis focused on the recipient of the translation, those differences lead to employing different translation strategies. For example, in some texts the intervention of the translator, e.g. in the form of a translator's note, may prove useful for the recipient of the document, usually a Swedish court or institution. While guidelines for translators (Kierzkowska 2011: 15) consider foreign courts etc. to be distant recipients, in two described scenarios (case 1, case 3 ) it was suggested to classify the recipients as quasi-distant. These cases confirm that the issue of recipient category, and as a consequence also the choice of the appropriate translation strategy, is not trivial. As far as the Polish equivalents used by self-defined recipients and customers are concerned, i.e. the Swedish Social Insurance Agency Försäkringskassan, they suggest the usefulness of pragmatic equivalents. This terminology should be recommended to Swedish-Polish translators. It would also appear that there is a need for a more comprehensive database of maintenance-related terminology, also for the Polish-Swedish language pair.

\section{N O T E S}

1 The research financed from the research grant no. DEC-2012/07/E/HS2/00678, titled: Parametrization of legilinguistic translatology in the scope of civil law and civil procedure awarded by the National Science Centre of the Republic of Poland (Sonata Bis program).

2 http://www.tnc.se/Rikstermbanken/rikstermbanken-alla-termer-pa-ett-stalle.html 
3 The Polish term alimenty also belongs to the vernacular language.

${ }^{4}$ It is widely considered to be very low. Even if, for example, the child is the only dependant and the mother earns the minimum national wages (approx. 1750 PLN), he/she is already excluded from receiving the benefit.

${ }^{5}$ https://sv.glosbe.com

6 www.forsakringskassan.se

\section{R E F E R E N C E S}

Bogdan, M. 2014: Svensk internationell privat- och procesrätt. Stockholm: Norstedts Juridik.

Carlson, L. 2012: The Fundamentals of Swedish Law. A Guide for Foreign Lawyers and Students. Lund: Studentlitteratur.

Delisle J., Lee-Jahnke, H. \& Cormier, M.C. 1999, (eds.). Translation Terminology. Amsterdam/Philadelphia: John Benjamins Publishing Company.

Ignaczewski, J. 2014. Alimenty: komentarz. Warszawa: Wydawnictwo C.H. Beck.

Jurdyk, A. 2012: Alimenty w prawie prywatnym międzynarodowym. Warszawa: LexisNexis.

Kierzkowska, D. 2002: Tłumaczenie prawnicze. Warszawa: Wydawnictwo Tepis.

Kierzkowska, D. 2011: Odbiorcy tłumaczenia tekstu pragmatycznego czyli teoria o praktyce. In: Lingua Legis, Vol. 20, 11-16. Warszawa: Wydawnictwo Translegis.

Koller, W. 1995: The Concept of Equivalence and the Object of Translation Studies. In: Target, Vol. 7.

Kubitsky, J. 1995: Stownik polsko-szwedzki. Polsk-svensk ordbok. Stockholm: Natur och Kultur.

Matulewska, A. 2013. Legilinguistic Translatology. A parametric Approach to Legal Translation. Franfurt am Main: Peter Lang Publishing House.

Šaračevič, S. 1997: New Approach to Legal Translation. Kluver Law International.

Tomaszewska, E. 2014. Ustawa o pomocy osobom uprawnionym do alimentów: komentarz. Warszawa: LexisNexis.

Vermeer, H.J. 2001: Skopos and Commission in Translational Action. In: L. Venuti \& M.Baker (eds.), The Translation Studies Reader, 221-232. London, New York: Routlege.

\section{Source texts}

Föräldrabalk given Stockholms Slott den 10 juni 1949, SFS 1949:381 (Kap. 7 Om underhållsskyldighet)

Socialförsäkringsbalken utfärdad den 25 februari 2010, SFS 2010:110. 
Milena Hadryan

Ustawa z 25.2.1964 r. - Kodeks rodzinny i opiekuńczy (Dz.U. z 2012 r. poz. 788 ze $\mathrm{zm}$.

Ustawa z dnia 7 września 2007 r. o pomocy osobom uprawnionym do alimentów (tekst jedn. Dz.U. z 2012 r., poz. 1228 ze zm.) 